Studies in African Linguistics

Volume 28, Number 1, Spring 1999

\title{
IS THERE A PASSIVE IN DHOLUO?
}

\author{
Eunita D. A. Ochola \\ University of South Carolina \\ Kenyatta University
}

This article presents an analysis of a particular passive-like syntactic construction in Dholuo, a Nilotic language spoken in parts of Kenya, Uganda, and Tanzania. While the construction analyzed resembles the passive construction in English in which the fronted patient/theme is the subject NP, the analysis shows that this construction is not a true passive in Dholuo, but rather a pseudo-passive. The peculiarity of the Dholuo pseudo-passive is that the fronted patient is not the NP subject of the construction; rather, it is a preposed object that is adjoined to IP. What distinguishes this construction from "classic" passive constructions is that the preposed object does not control subject verb agreement.

\section{Introduction}

Dholuo, also known as Luo, is a Western Nilotic language spoken by approximately three million people in south-western Kenya and north central Tanzania east of Lake Victoria. The particular dialect discussed in this paper is spoken in Nyanza Province, Kenya. Closely related languages include Acholi and Lango, spoken in Uganda. Dholuo is one of the four largest languages in Kenya and is the only non-Bantu language among them.

This paper presents an analysis of a particular syntactic construction in Dholuo that looks superficially like a passive. In (1a), for example, Chàlí, the patient, precedes the verb, and Dòrínà, the agent, follows the verb in a prepositional phrase, gi Dòrinà by Dorina'. However, I propose that this construction is not a true passive.

(1)
a. Chàlí n-ò-gò
gi Dòrínà.
Chali PST-EXPL-beat by Dorina
'Chali was beaten by Dorina.'

b. [IPChàlíj [IP pro $\mathrm{i}$-òigò t $\mathrm{j}_{j}$ gi Dòrínà ]] 
In the analysis developed here, I argue that the patient Chàli in (1) is not a subject, but a preposed object that is adjoined to IP, following the X-bar conventions of the Government and Binding framework [Chomsky 1995]. The fact that the fronted NP is adjoined to the Specifier of IP, and not to COMP or Specifier of CP, and remains within the highest IP, gives this construction its passive-like flavor and contributes to the surface similarity of this pseudopassive with real passives. That is, the fronted NP appears to remain within IP, a property of subject NPs. It remains to the left of other moved elements, such as topicalized or clefted constructions.

Under the analysis presented here, in which (1a) is bracketed as in (1b), there must be a null pronominal subject coindexed with the subject agreement prefix on the verb. The passive agent must be base-generated as an adjoined PP. The preposed patient in this construction does not occur in subject position; that is, it does not move into an empty NP position in Specifier of IP. Evidence for this analysis comes from subject-verb agreement, object cliticization, case and tone assignment in Dholuo.

The paper is organized into the following sections. Section 2 illustrates some basic facts about Luo. Section 3 considers case assignment in Dholuo as compared to English passive sentences. Section 4 gives evidence from object clitics that supports the claim for a pseudo-passive construction in Dholuo. Section 5 shows the interaction of topicalization and NP objects with object clitics, providing further evidence that supports the analysis that the fronted NP in examples like (1) remains within the IP. The final section concludes; Dholuo has a pseudo-passive in which the fronted NP is not the subject of the sentence.

\section{Word order in active and pseudo-passive sentences}

In Dholuo, word order in active sentences is typically SVO, as shown in (2). Examples (2a) and (2c) illustrate active sentences with both agent and patient present; in both, the agent Dórína precedes the verb and the patient, Chàlí, follows. In (2b), there is a null pronominal subject coindexed with agreement morphology on the verb, which shows that Dholuo is a null subject language. In (2c) the object is one of a set of pronouns. Such pronouns are clitics; that is, they must immediately follow the verb. Although there is a $g i$-phrase in (2d) and (2e), only an active reading is possible. And although the gi-phrase ("with $\mathrm{X}^{\prime}$ ) must be interpreted as an instrument (not an agent), an instrumental interpretation is not possible for (2d) for pragmatic and semantic reasons. Rather, it can mean that Chali was beaten alongside Dorina because the agreement on the verb in (2d) and (2e) is the same as the agreement in $(2 \mathrm{a}-\mathrm{c})$; the null subject is coindexed with the third person singular prefix $o$. Example (2f) shows that a prepositional phrase (here kòd Dòrinà) can occur after the verb. Such a PP is interpreted as a comitative; that is, it is treated as if conjoined to 
the preceding object, including a pronoun clitic. Note that in (2d-f) the pronominal clitics yà/yì 'me/you' would also be possible in place of yè.

(2) a. Dórínà n-ó-gò Chàlí.

Dorina PST-3S-beat Chali

'Dorina beat Chali.'

b. n-ó-gò Chàlí.

PST-3S-beat Chàlí

's/he beat Chali.'

c. Dórínà n-ó-gò (*nyoro) yè.

Dorina PST-beat (yesterday) $3 \mathrm{~S}$

'Dorina beat him/her (*yesterday).'

d. n-ó-gò Chàlílyè gi Dórínà.

PST-3S-beat Chàlí/him with Dòrínà

*S/he beat Chali//him/her with Dorina [instrumental reading]

'S/he beat Chali//him/her with Dorina.' [comitative reading]

e. n-ó-gò Chàlílyè gi kédè.

PST-3S-beat Chali/him/her with stick

'S/he beat Chali//him/her with a stick'

f. n-ó-gò Chàlílyè kòd Dórínà.

PST-3S-beat Chali//him/her and Dòrínà

'S/he beat Chali//him/her and Dorina.'

As noted in the introduction, the focus of this paper is the superficially passive construction shown in (1) and repeated below in (3a). However, close examination suggests that it is not, in fact, a true passive, but rather what I refer to throughout the rest of the paper as a pseudo-passive. This pseudo-passive construction comprises a thematic patient, and, optionally, an agent in an adjunct PP (gi Dòrínà). ${ }^{1}$ The thematic patient is an NP (Chàlí in (3a-b, d). While the thematic patient precedes the verb in (3a), as in a proto-typical passive, it follows the verb in (3b) and (3d). That is, the order of constituents in (3d-e) is $V$-O-by Agent. When the patient is a pronominal clitic, the sentence can still have a passive reading, as in (3c) and (3e), and can occur with an agent in a $g i$ phrase, as in (3e). In all of these examples, the agreement prefix on the verb is

1 See Dubinsky \& Nzwanga's [1994] argument on impersonal transitives in a Bantu language spoken in Zaire. 
glossed as EXPL (for expletive agreement). This agreement pattern is discussed below.

(3) a. Chàlí n-ò-gò gi Dòrínà.

Chali PST-EXPL-beat by Dorina

'Chali was beaten by Dorina.'

b. n-ò-gò Chàlí.

PST-EXPL-beat Chali

'Chali was beaten.'

c. n-ò-gò yè.

PST-EXPL-beat $\mathrm{s} / \mathrm{he}$

'S.he/me/you were beaten.'

d. n-ò-gò Chàlí gi Dòrínà.

PST-EXPL-beat Chali by Dorina

'Chali was beaten by Dorina.'

e. n-ò-gò yè gi Dòrínà.

PST-EXPL-beat s/he by Dorina

'S/he was beaten by Dorina.'

A comparison of $(2 a-c)$ with $(3 a-c)$ shows that when the sentence has a passive reading, the agreement prefix on the verb has a low tone, $\grave{o}$, not a high tone, $o$. This feature of agreement is significant in the analysis of the pseudopassive construction in Dholuo because it determines the interpretation of voice (as active or passive). I refer to this form of agreement on the verb as "expletive" agreement because the form of the agreement does not vary with respect to the subject/agent (or the object/patient). This interaction of tone and INFL is discussed more in the next section.

\section{Comparing Dholuo and English: Subject-verb agreement and tone}

At first glance, (3a) resembles the English-type passive construction in which the fronted patient/theme is the subject NP, as in (4). Within GB-analyses, case assignment motivates movement in English. The English passive verb neither assigns an external theta-role to an agent NP nor accusative case to its object NPs [see Burzio 1986, Chomsky 1981, Chomsky and Lasnik 1977, Goodall 1993, Emonds 1970, Aoun 1979, Grieve and Wales 1973, Baltin 1978, Belletti 1988, Belletti, and Rizzi 1981, and Rothstein 1992]. For example, in (4a) the passive verb beaten fails to assign accusative case to its internal argument Chàlí; 
rather, Chàlí is assigned nominative case by INFL after movement. In addition to receiving nominative Case from INFL, passive subjects in English-type languages also control agreement on finite verbs in INFL. For example, in (4b) were agrees with the men.

(4) a. Chali was beaten by Dorina.

[IP Chali [I-bar wasi $_{i}$ beaten $\mathrm{e}_{\mathrm{i}}$ [PP by Dorina]]

$\left[\right.$ Chali $i \leftarrow$ Case $_{\text {NOM }}$ INFL....beaten $\theta$-role $\rightarrow \mathrm{e}_{\mathrm{i}}$

[by $\theta$-role/Case ${ }_{\mathrm{OBJ}} \rightarrow$ Dorina]]

b. The men were beaten by Dorina.

[IP The men [I-bar were $_{i}$ beaten $\mathrm{e}_{\mathrm{i}}$ [PP by Dorina]]

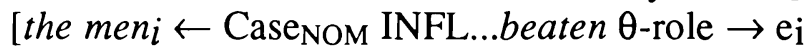

$\left[\right.$ by $\theta$-role/Case ${ }_{O B J} \rightarrow$ Dorina]]

Evidence from how subject-verb agreement in Dholuo interacts with tone shows that the construction in question involves object fronting rather than passivization. First, in active transitive sentences, the subject-verb agreement prefix has a high tone, as pointed out previously in the discussion of (2), not the low tone expletive prefix of the construction illustrated in (3). If the tone on the agreement morpheme in a sentence intended to be interpreted as active is low, the sentence is ungrammatical. Compare (5), in which the verb prefix has a high tone as in an active sentence, with (6), in which the verb prefix is a low tone.

(5)
Chàlí n-ó-gò Dòrínà.
Chali PST-3S-beat Dorina
'Chali hit Dorina.'

(6)
*Chàlí n-ò-gò
Dòrínà
Chàlí PST-EXPL-beat Dorina
(Chali beat Dorina; Chali, Dorina was beaten)

In motivating passive in English-type languages, thematic role assignment also interacts with case assignment. In the analysis of the English passive, Baker, Johnson, and Roberts [1989] claim that the morpheme -en, as in (4) above, is an argument that is base generated under INFL and is in a theta-marked position at D-structure (see also the discussion in Dryer [1985]). Others (cf. Goodall [1993] and Grimshaw [1990, 1979]) have shown that it is not possible to assign an appropriate thematic role to an NP following the verb. Example (6) above shows post-verbal Dòrínà cannot receive a thematic role if an NP precedes a verb-here Chàlí-with a low tone agreement prefix. This means that verbs with expletive agreement prefixes no longer assign an agent thematic role; as in 
English, the agent receives both thematic role and case from the preposition $g i$ 'by'.

Similar facts obtain for impersonal passives with fronted plural NPs (as in (7a)), in which the verb also occurs with the low-toned agreement marker like the pseudo-passive. Compare the active (7b) with passive (7a); a high tone occurs on the verb agreement prefix in (7b). In addition, if the agent is nonthird person, as in (7c), the verb agrees with the agent in the active reading. In (7c), the verb agrees with a null first person singular pronoun. Compare (7c) with its pseudo-passive counterpart in (7d). In such examples, the verb does not agree with the non-third person agent, which occurs in a gi phrase. Note that an agent NP in a gi-phrase (here an 'me') cannot control agreement on the verb, illustrated by the ungrammatical example in (7e). This means that the pseudopassive construction in Dholuo cannot be argued to be an active construction with simple object fronting.

(7) a. Chúò n-ò-gò (gi Dòrínà).

men PST-EXPL-beat (by Dorina)

'The men were beaten (by Dorina).'

b. Dòrínà n-ó-gò Chúò.

Dórínà PST-3S-beat men

'Dorina beat the men.'

c. n-á-gò Dòrínà.

PST-1S-beat Dorina

'I beat Dorina.'

d. Dòrínà n-ò-gò $\quad$ gì àn.

Dorina PST-EXPL-beat by me

'Dorina was beaten by me.'

e. *Dòrínà n-á-gò gì àn

Dorina PST-1S-beat by me

'Dorina, I beat by me'

Thus, evidence from subject-verb agreement shows that the when a lowtoned $-\grave{o}$ - prefix occurs on the verb, no overt NP controls agreement, neither the preposed NP nor the NP in the gi phrase. Additional evidence that the construction in question is not a grammatical relation-changing passive in which an NP moves into an Argument-position and that it is an impersonal passive also comes from the interaction of subject-verb agreement with pronominal object cliticization, the subject of the next section. 


\section{Object Clitics}

Object clitics also support a fronting and adjunction analysis versus a passive analysis for the Dholuo pseudo-passive construction. Active transitive verbs occur with pronominal object clitics immediately following the verb, as noted previously and as illustrated in (8b). In active sentences, a post-verbal object clitic-for example -yè, -ỳ̀, or -yà 'him/her, you, me', respectively—can occur in place of an NP such as Chàli (8a), as shown in (8b).

(8) a. Dòrínà n-ó-gò Chàlí.

Dorina PST-3S-beat Chali

'Dorina beat Chali.'

b. Dòrínà n-ó-gò-yè/yì/yà.

Dorina PST-3S-beat-3S/2S/1S

'Dorina beat him/her/it//you//me.'

Post-verbal clitics expressing the internal object (patients/themes) of verbs also occur in the impersonal passive construction in Dholuo. The patient controls object cliticization, as in (9b). Examples (9b-c) illustrate that subject NPs only control subject verb agreement, not object cliticization; in these examples a non-third person subject controls agreement. This contrasts with the "passive" reading of the sentence in (9a); the sentences in (9b) and (9c) with non-third person subject-verb agreement have only active readings (with generic objects). That is, the grammatical subject is an agent NP, not a patient. In (9a), however, the NP interpreted as the patient controls object cliticization, and not subject-verb agreement.

a. n-ò-gò-yè/yì/yà.

PST-3S-beat-3S/2S/1S

'She/he/it//you//I was/were beaten.'

b. n-á-gó chò.

PST-1S-beat something

'I was beating/beat (something).'

c. n-í-gó chò.

PST-2S-beat something

'You were beating/beat (something).'

The examples in (8) and (9) also illustrate a second aspect of Dholuo morpho-syntax already noted; that is, Dholuo is a null pronominal language. The object clitic co-occurs with a null patient (compare (8b) and (9a)) and the 
subject agreement prefix can co-occur with a null agent (compare (9b) and (9c)). In addition to clitic and agreement-licensed null pronominals, Dholuo also has overt pronouns. These are emphatic pronouns which can co-occur with clitic pronominals. The distribution of fronted pronominals, clitics, and subject-verb agreement provides additional evidence for the fronting analysis of the impersonal passive in Dholuo.

4.1 Clitics vs. pronouns. In Dholuo, post-verbal pronominal objects only occur as clitics, not free-standing pronouns. Compare the grammatical (10a) with the ungrammatical (10b). In (10a), a first person object clitic -yà 'me' occurs alone. In the ungrammatical $(10 \mathrm{~b})$, the free-standing pronoun àn 'me, myself' occurs. The free-standing pronoun àn cannot occur in post-verbal position, even if it co-occurs with an agreeing object clitic (-yà), as in (10c). This means that object clitics and post-verbal pronouns are in complementary distribution. Likewise, post-verbal NPs cannot occur with an object clitic, as illustrated in (10d), where Chàlí co-occurs with the third person singular object clitic -yè.

(10) a. Dòrínà n-ó-gó-yà.

Dorina PST-3S-beat-1S

'Dorina beat me.'

b. *Dòrínà n-ó-gó àn

Dorina PST-3S-beat $1 \mathrm{~S}$

(??'Dorina beat myself’)

c. *Dòrínà n-ó-gó-yài àn $i$

Dorina PST-3S-beat $1 \mathrm{~S}$

(??'Dorina beat myself’)

d. *Dòrínà n-ó-gó-yè $i \quad C h a ́ l i ̀ i$

Dorina PST-3S-beat-3S Chali

('Dorina beat himi Chali $_{i}$ ')

Although independent, free pronouns cannot occur post-verbally, such pronouns can occur pre-verbally. In (11), for example, an optional first person pronoun occurs before the verb. In this example, the pronoun agrees with the subject-agreement on the verb. Note that the tone on the verb agreement morpheme is high; this is an active sentence, with an emphatic subject reading. 
(11) (ân) n-á-gó-yè.

1S PST-1S-beat-3S

'Me, I beat him.'

Example (11) contrasts with (12a), in which àn 'I, me' is pre-verbal, but it fails to control subject verb agreement. However, in this example, it does control obligatory object cliticization of -yà on the verb. Compare the grammatical (12a) with the ungrammatical (12b) and (12c). In (12b), the independent pronoun an occurs preverbally without the object agreement clitic -ya, and in (12c), the object clitic -yè 's/he' which occurs does not agree with the preverbal pronoun ân 'me'.
(12) a. ân n-ò-gò-yà
(gi Dòrínà).
I/me PST-EXPL-beat-1S (by Dorina)
'I was beaten (by Dorina).'
b. *ân n-ò-gò $\quad$ (gi Dòrínà)
I/me PST-EXPL-beat-1S (by Dorina)
('I was beaten (by Dorina)')
c. *ân $\quad n$-ò-gò-yè
I/me PST-EXPL-beat-3S
('I was beaten him/her')

These facts regarding restrictions on the distribution of pronouns suggest that pronominals in Dholuo are emphatic. They are restricted to discourseemphatic positions-for example, Topic position-and are adjoined to the beginning of the sentence. In turn, the co-occurrence restrictions of these emphatic pronominals, subject-verb agreement, and object clitics again suggest that the fronted NP in pseudo-passives is not a subject and the construction in question is not a true passive.

\subsection{Object clitics with coreferential pronouns vs. NP fronting. As} noted above, a pre-verbal pronoun can occur with a coreferential subject agreement prefix, as in (11), or a post-verbal object clitic, as in (12a). The ability of object clitics to occur with fronted pronominals contrasts with their inability to occur with fronted NPs, as shown in (13a), in which a fronted nominal Chàlí cannot co-occur with postverbal clitic yè. However, if a fronted nominal Chàlí also occurs with a preverbal discourse emphatic pronominal en, as in (13b), it can also occur with a post-verbal clitic yè, as in (13b). Compare (13a) and (13b). In both of these examples, the agreement prefix is the lowtoned expletive marker. Note that if the tone were high in (13c), it would be 
ungrammatical because Chàlí would be assigned both the patient role (agreeing with the post-verbal clitic yè) and agent role (agreeing with the high-toned subject prefix ó).

In sum, the facts regarding object cliticization and overt pronominals support the fronting versus passive analysis. Object clitics may occur by themselves or they may co-occur with overt pronouns. When overt pronouns co-occur with object clitics, they may not control subject-verb agreement. Overt pronouns occur only preverbally, not postverbally.

\section{Identifying the fronted NP}

So what is the Dholuo pseudo-passive construction? While it resembles an indefinite subject construction, it is not one. First, the agent can be provided in a PP as has been illustrated throughout this paper. Second, the pseudo-passive construction occurs alongside a clear indefinite subject construction in Dholuo in which the implied subject is always third person plural gi. Compare the indefinite subject construction illustrated in (14a) with the comparable pseudopassive in (14b-c). Only in (14b-c) is a PP with an agent possible. In addition, in (14b-c), the verb does not agree with ràbúòndé 'potatoes' (or the agent PP gi mòn 'by the women').

(14) a. Né-gí-tédò ràbúòndè kàmà (*gi mòn).

PST-3P-cook potatoes like this (*by women)

'They cooked potatoes like this (*by the women).'

b. Ràbúòndè n-ò-tèdí kàmà (gi mòn). potatoes PST-EXPL-cook like this (by women) 'The potatoes were cooked like this (by the women).' 


\section{c. n-ò-tèdí ràbúòndè kàmà (gi mòn).}

PST-EXPL-cook potatoes like this (by women)

'the potatoes were cooked like this (by the women).'

Thus far I have demonstrated that the pseudo-passive construction is not a true passive. The fronted NP does not control subject-verb agreement. If the fronted NP is a pronoun, it must co-occur with an object clitic on the verb. While the verb has agreement morphology in INFL, the form is different from other agreement prefixes. If this construction is neither a real passive nor an impersonal active construction, as in (14a), what is it? One possible analysis is that the construction in question involves topicalization. The simplest analysis would be a fronted NP outside of IP and adjoined to COMP, as in Figure 1.

Figure 1. XP Adjoined to Specifier of COMP

(Topicalization, WH-movement)

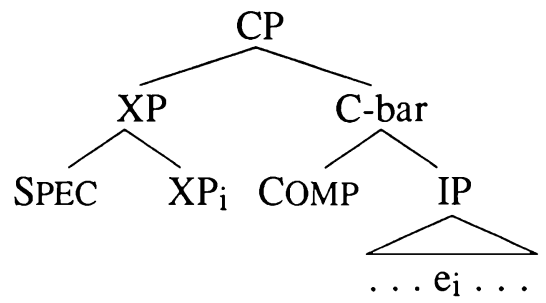

$\left[\mathrm{CP}\left[\mathrm{XP} \ldots \mathrm{XP}\right.\right.$ i] [C-bar [COMP] [IP ... e $\mathrm{e}_{\mathrm{i}} \ldots . . \mathrm{C}$-bar $\left.] \mathrm{CP}\right]$

Figure 2. XP Adjoined to Specifier of INFL (Pseudo-Passive)

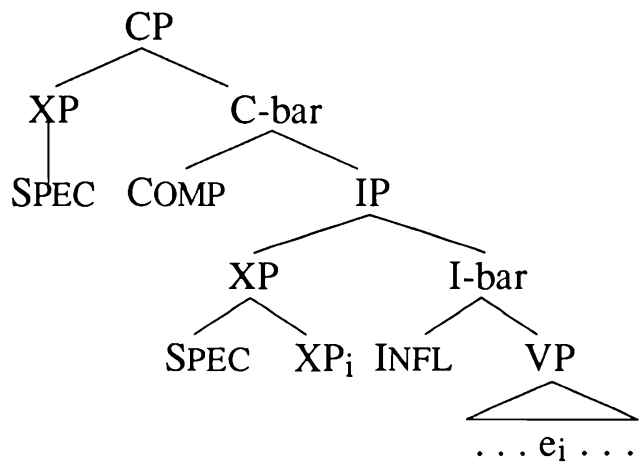

[CP [XP ] [C-bar [COMP ] [IP [XP ... XP

[I-bar [INFL ] [VP ... $\left.e_{i} \ldots ..\right]$ I-bar] IP] C-bar] CP] 
However, I propose that the NP fronting in constructions like (2a) is not like other movement to Specifier of COMP, such as Topicalization and WH-movement (see Takami and Kamio [1996]). Instead, I propose that the fronted NP is still within IP, as in Figure 2, and is adjoined to Specifier of INFL. Evidence from topicalization and WH-movement support this analysis.

5.1 Evidence from topicalization. What is the evidence that the moved NP is within the IP and not adjoined to Specifier of CP? Some evidence comes from topicalization. In topicalized intransitive constructions, an overt pronoun cooccurs with the subject NP. Both the overt nominal NP and pronominal agree with the verb, as in (15) in which Chàli controls subject-verb agreement and can co-occur with the emphatic pronoun en.
(15)
Chàlí (èn) n-ó-bírò.
Chali him PST-3S-come
'Chali, him, he came.'

Emphatic, topicalized object NPs may not co-occur with an object clitic, as shown in (16a) in which Dorina and the object clitic agree, but in which Chàlí controls subject-verb agreement. However, a preverbal pronominal may occur, as in (16b), in which Dorina and en both precede the verb and agree with the object clitic ye. One unique feature of topicalization of non-subjects in Dholuo is that the tense can be separated from the rest of the verb by an intervening subject NP. See also (16c), in which tense (ne) precedes the subject Chàli. ${ }^{2}$

(16) a. *Dòrínà Chàlí n-ó-gó-yè

Dorina Chali PST-3S-beat-3S

('Dorina, Chali beat her')

b. Dòrínà én Chàlí n-ó-gó-yè.

Dorina s/he Chali PST-3S-beat-3S

'Dorina, Chali beat her.'

c. Dòrínà né Chàlí ó-gó-yò.

Dorina PST Chali 3S-beat-3S

'Dorina, Chali beat her.'

2 In this construction, the object suffix no longer harmonizes with the tense prefix and occurs as yo rather than as ye. 
Topicalized NPs can also be emphasized in a cleft construction in which the tense occurs with the clefting structure, instead of with the verb, as in (17). 3 The tense prefix né precedes the subject $C$ hàlí. The form of the object suffix also changes in a clefted structure (from ye to $y o$ ).

(17) Dòrínà é-mà né Chàlí ó-gó-yò.

Dorina 3S-EQ PST Chali 3S-beat-3S

'It was Dorina who Chali beat.'

Note that in (16) and (17), the tone on the subject-agreement prefix is high, not low, as in the pseudo-passive construction under consideration. Also, in (16), the subject NP Chàli is pre-verbal. In contrast, the agent of the pseudopassive is optional and occurs in a $g i$-phrase. In addition, in topicalized and clefted constructions, the overt nominal preposed object NP Dòrínà co-occurs with the object clitic yò without the occurrence of an preverbal discourse pronoun en. Recall that in the pseudo-passive construction under analysis, only if the fronted NP is a pronominal or co-occurs with a pronoun, can it co-occur with an object clitic. In sum, evidence from topicalization and cleft constructions supports the analysis in which pseudo-passive in Dholuo is not an instance of fronting and adjunction to COMP or Specifier of COMP. This suggests that the pseudo-passive construction does not always have the function of emphasizing the object NP, as would topicalization of an object.

5.2 More evidence from topicalization. Additional evidence from topicalization indicates that the moved NP in the pseudo-passive stays within IP. Recall (16c) in which tense occurs between the topicalized NP and the rest of the IP. This is "visible" because of the intervening subject Chàlí. Additional examples illustrating topicalization are given in (18). In (18a) an object NP, ràbúòndé 'potatoes', is topicalized; in (18b) an adverb nyórò 'yesterday' is topicalized. In both of these examples, the past tense morpheme nyé has been fronted before the subject NP Dòrinà. The examples in (18c-d) show how topicalization interacts with the pseudo-passive construction under consideration. In (18c), an adverb nyoro occurs before past tense nyé and the fronted object ràbúòndé 'potatoes' occurs preverbally. The agent Dòrínà occurs in a post-verbal gi-phrase. In contrast, if the object ràbúondé precedes past tense nyé, the adverb cannot be fronted by the pseudo-passive; hence, (18d) is ungrammatical.

3 The equative/copular morpheme ma of the cleft structure is also used for adjective constructions. The clefted NP controls agreement on ma. 
(18) a. Ràbúòndè nyé Dòrínà ó-tèdò nyórò.

potatoes PST.TOP Dorina 3S-cook yesterday

'Potatoes, Dorina cooked (them) yesterday.'

[Compare Dòrínà n-ó-tèdò ràbúòndè nyórò]

b. Nyórò nyé Dòrínà ó-tèdò ràbúòndè. yesterday PST.TOP Dorina 3S-cook potatoes 'Yesterday, Dòrínà cooked potatoes.'

c. Nyórò nyé ràbúòndè ò-tèdí gi Dòrínà. Yesterday, PST-TOP potatoes EXPL-cook by Dorina 'Yesterday, potatoes were cooked by Dorina.'

d. *Ràbúòndè nyé nyórò ò-tèdí gi Dòrínà potatoes PST.TOP yesterday EXPL-cook by Dorina 'Potatoes, Dorina cooked (them) yesterday.'

(Compare Dòrínà n-ó-tèdò ràbúòndè nyórò]

This interaction of topicalization and pseudo-passive illustrated in (18c) provides another reason for the passive-like flavor of the pseudo-passive in Dholuo. The fronted NP clearly remains within IP; it cannot occur outside of the scope of elements outside of Tense, as in (18d). That is, the interaction of these two movement rules indicates that while topicalization moves an element outside of IP, the pseudo-passive does not. In fact, this interaction tells us where the NP of the pseudo-passive moves to: if we assume that Tense-P (TP) under INFL raises to COMP, under head-to-head movement, then topicalization (as illustrated in (18a-c) moves an element into Specifier of COMP, and pseudopassive fronts an NP to the right of COMP. (See the discussion of head-movement in Chomsky [1995]). The fronted NP must be adjoined to Specifier of INFL (see the schema in (19)). The Topicalized NP (Top NP ${ }_{k}$ ) is coindexed with a trace left in the IP. The Tense Phrase $\left(T_{t}\right)$ is coindexed with a trace in INFL. The fronted NP $\left(\mathrm{NP}_{\mathrm{i}}\right)$ is coindexed with a direct object trace. A null NP occurs in Specifier of IP as the dummy subject, and it is coindexed with agreement $\left(\mathrm{AP}_{\mathrm{a}}\right)$ in INFL.

(19) $\left[\mathrm{CP}\left[\right.\right.$ SPECTop NP $\mathrm{N}_{\mathrm{k}}\left[\mathrm{C}-\mathrm{BAR}\left[\mathrm{COMP} \mathrm{TP}_{\mathrm{t}}\right]\left[\mathrm{IP}\left[\mathrm{XP} \mathrm{NP}_{\mathrm{i}}\right]\left[\operatorname{SPEC} \varnothing_{\mathrm{a}}\right]\right.\right.$ [I-BAR [INFL e $\left.\left.e_{t} \operatorname{AgrP}_{a}\right] \ldots V e_{i} \ldots e_{k}\right]$

Additional evidence that the fronted NP does not move outside of IP, as in topicalization or WH-movement, is that tense cannot move along with the fronted NP; the full form of the past marker should occur, not just the contracted form with the expletive agreement inflection, nò. But in the construction 
in question, tense cannot occur separated from AGR. Compare the ungrammatical (20a) and (20b) with (18a-c).

(20)
a. *né Dòrínà ò-gó
(gi Chàlî)
PST Dorina EXPL-beat (by Chali)
('Dorina was beaten by Chali')
b. *Dòrína né-ò-gó $\quad$ (gi Chàlî
Dorina PST-EXPL-beat (by Chali)
('Dorina was beaten by Chali')

\section{Conclusion}

Although Burzio's [1996] generalization regarding the role of case assignment motivating NP-movement in passives works for languages such as English, the characterization of passive constructions in terms of linear order, case marking, and verbal morphology relates more to language-specific tendencies than to universal grammar. This is consistent with the claims of Perlmutter [1983] (see also Perlmutter \& Postal [1993]). The analysis and evidence presented in this paper show that, while the pseudo-passive construction appears superficially to be a passive construction, NP movement in this construction is not motivated by case assignment-instead, the fronted NP receives accusative case-and therefore cannot be termed a true passive in the terms of Burzio [1986].

If not a true passive, what, then, are the properties of what I have called the pseudo-passive construction? First, we have seen that a pronominal object is fronted and the fronted NP co-occurs with an object clitic on the verb. Because the fronted NP is coindexed with either an object clitic or a null marker in object position, it inherits accusative case from the right most member of its chain [Aoun 1979]. Second, the fronted NP moves to a different place from a topicalized or WH-moved element-hence, the construction is not a case of topicalization-because, in these constructions, the tense can occur before the subject. Under head-to-head movement, we can assume that the fronted tense moves under COMP. If the fronted NP moves outside of IP, as a topicalized NP or WH-moved NP does, tense should be able to move along with it and the full form of the past marker should occur, not just the contracted form with the expletive agreement inflection, $n-\grave{o}$ (PST-EXPL). But this does not happen. (Recall the ungrammatical (20).) These facts suggest that the fronted NP in the Dholuo pseudo-passive remains within the IP, and adjoins to Specifier of IP position, and that the Specifier position itself is filled by the base-generated nonthematic null pronominal, controlling subject-verb agreement. However, the fronted NP is not base-generated because it can also occur post-verbally (recall and compare (3a) and (3b). The patient NP need not be fronted. 
So, is there a passive in Dholuo? Not as a relation-changing movement rule. But there is the pseudo-passive construction in which a fronted NP has very interesting properties. Through the use of a null subject construction, a patient NP can be emphasized. Moreover, movement of the patient is an optional additional focusing property of the construction, since the "passive" reading obtains even without the fronting of the patient. In addition, Dholuo exhibits at least four distinctions of terms of identification of agency. In the active, the agent is clearly identified. In the pseudo-passive, the agent may be optionally identified, but without being focused. Moreover, in this pseudo-passive, the agent can also be omitted. Finally, in the generic subject construction, the agent is marked as understood by context, but it is neither suppressed nor less focused than the passive agent in a gi-phrase.

In sum, the analysis presented in this paper reveals two interesting features of the Dholuo pseudo-passive. First, it shows that unlike languages such as English, the only difference between the Dholuo pseudo-passive and its counterpart active construction is tone placement on the verbal morphology. More interestingly, evidence presented in this paper shows that the Dholuo pseudopassive has more properties in common with a true passive in English than pseudo-passives in other languages (e.g., the impersonal passives in Lingala). For instance, the $g i$ 'by' phrase in the PP position in the Dholuo pseudo-passive is a common characteristic of a true passive in languages such as English. Moreover, the NP movement illustrated in the Dholuo pseudo-passive is another characteristic of a true passive. These peculiar properties of the Dholuo pseudopassive present an interesting phenomenon for further grammatical investigation.

\section{REFERENCES}

Aoun, Joseph. 1979. "On government, case marking, and clitic placement." Ph.D. dissertation, MIT.

Baltin, Mark. 1978. "Towards a theory of movement rules." Ph. D. dissertation, University of Illinois at Urbana-Champaign.

Baker, Mark, Kyle Johnson, and Ian Roberts. 1989. "Passive arguments raised." Linguistic Inquiry 20: 219-251. 
Belletti, Adriana. 1988. "The case of unaccusatives." Linguistics Inquiry 19: $1-43$.

Belletti, Adriana and Luigi Rizzi. 1981. "The syntax of 'ne': Some theoretical implications." Linguistic Review 1: 117-154.

Burzio, Luigi. 1986. Italian syntax, a government-binding approach. Dordrecht: Reidel.

Chomsky, Noam. 1981. Lectures on Government and Binding. Dordrecht: Floris.

Chomsky, Noam. 1995. The Minimalist Program. Cambridge, MA: The MIT Press.

Chomsky, Noam and Howard Lasnik: 1977. "Filters and control." Linguistic Inquiry 8: 425-504.

Dryer, Matthew. 1985. "The role of thematic relations in adjectival passive." Linguistic Inquiry 16: 320-326.

Dubinsky, Stanley and Mazemba Nzwanga. 1994. "A challenge to Burzio's generalization: impersonal transitive in western Bantu." Linguistics 32: 47-64.

Emonds, Joseph. 1970. Roots and Structure Preserving Transformations. Bloomington, Indiana: Indiana University Linguistics Club.

Goodall, Grant. 1993. "On case and the Passive." Natural Language and Linguistic Theory 11, 1: 31-42.

Grimshaw, Jane. 1990. Argument Structure. Cambridge, MA: MIT Press.

Grimshaw, Jane. 1979. "Complement selection and the lexicon." Linguistic Inquiry 10: 279-326.

Grieve, Robert and Roger J. Wales. 1973. "Passives and topicalization." British Journal of Psychology 2: 173-182.

Perlmutter, David and Paul Postal. 1993. "On the formal theory of government." Linguistic Review 3: 44. 
Rothstein, Susan. 1992. "Case and licensing." Natural Languages and Linguistic Theory 10: 119-139.

Takami, Ken-ichi and Ako Kamio. 1996. "Topicalization and subjectivization in Japanese: Characterizational and identificational information." Lingua 99, 4: 207-235.

Department of Linguistics

University of South Carolina

Columbia, SC 29208

edochol@vm.sc.edu
[Received August 1998; revision received July 14,1999 ; accepted July 20, 1999] 